Pacific Journal of Mathematics

ASYMPTOTIC BEHAVIOR OF SOLUTIONS OF PARABOLIC
EQUATIONS OF HIGHER ORDER 


\section{ASYMPTOTIC BEHAVIOR OF SOLUTIONS OF PARABOLIC EQUATIONS OF HIGHER ORDER}

\section{LU-SAN CHEN}

It is known that the solution $u$ of the heat equation $\partial u / \partial t=\Delta u$ under the boundary condition $u=0$ decays as $e^{-\lambda t} u$ for some $\lambda>0$ as $t \rightarrow \infty$. This gives us information about the asymptotic behavior of the solution $u$ in time.

There arises the question whether such a theorem is valid for parabolic differential equations with variable coefficients.

In this note we shall treat this problem and prove that the theorem analogous to the above holds for parabolic differential inequalities of higher order under some additional restrictions.

Consider the unit sphere $\mathscr{D}$ in the $n$-dimensional Euclidean space $E^{n}$ with boundary $\Gamma$ and denote by $I(T)$ the interval $0 \leqq t \leqq T$ and by $I$ the half-infinite interval $0 \leqq t<\infty$. The $(n+1)$-dimensional domain $\mathscr{D} \times I$ will be designated by $R$, while $S$ will be the portion $\Gamma \times I$ of the boundary of $R$.

We are interested in the growth of functions $u(x, t)$ which satisfy the differential inequality of the form

$$
(L u)^{2} \leqq c(t) \sum_{|\alpha| \leqq s}\left|D_{x}^{\alpha} u\right|^{2}
$$

in $R$ and $D_{x}^{\alpha} u=0(|\alpha| \leqq s-1)$ on $S$. Here $L$ is a parabolic differential operator of higher order written in the form

$$
L \equiv(-1)^{s} \frac{\partial}{\partial t}-\sum_{|\alpha| \leqq 2 s} a_{\alpha} D_{x}^{\alpha},
$$

where all the coefficients $a_{\alpha}=a_{\alpha}(x, t)$ are $s$-times continuously differentiable in (a neighborhood of) $R \cup S$ and

$$
A \equiv \sum_{|\alpha| \leqq 2 s} a_{\alpha} D_{x}^{\alpha}
$$

$$
\left(D_{x}^{\alpha}=\frac{\partial^{|\alpha|}}{\partial x_{1}^{\alpha_{1}} \cdots \partial x_{n}^{\alpha_{n}}}, \alpha=\left(\alpha_{1}, \cdots, \alpha_{n}\right), \quad|\alpha|=\alpha_{1}+\cdots+\alpha_{n}\right)
$$

is assumed to be uniformly elliptic throughout $R \cup S$, i.e., there is a constant $k_{0}$ depending only on $A$ such that

$$
\sum_{|\alpha| \leqq 2 s} a_{\alpha} \xi^{\alpha} \geqq k_{0}\left(\xi_{1}^{2}+\cdots+\xi_{n}^{2}\right)^{s}
$$

for any real vector $\xi=\left(\xi_{1}, \cdots, \xi_{n}\right)$.

Let $v(x, t)$ be a $2 s$-times continuously differentiable function in 
$R \cup S$ such that

$$
D_{x}^{\alpha} v=0 \quad(|\alpha| \leqq s-1) \text { on } S
$$

and

$$
v(x, t)=0 \text { in }(x, t) \in \mathscr{D} \times I\left(T_{0}\right)
$$

for some $T_{0}$. The function $v$ satisfying (3) and (4) is said to belong to the class $V$.

We shall prove the following theorem.

THEOREM. Suppose that $u$ satisfies the inequality

$$
(L u)^{2} \leqq c(t) \sum_{|\alpha| \leqq s}\left|D_{x}^{\alpha} u\right|^{2}
$$

in $R \cup S$ and that $D_{x}^{\alpha} u(|\alpha| \leqq s-1)$ vanish on $S$ and suppose that the condition

$$
\lim _{t \rightarrow \infty} \int_{\mathscr{D}} e^{2 \lambda t} u^{2} d x=0
$$

holds for any $\lambda>0$. If $c(t)$ is bounded and continuous in $I$ and if $c(t)=0\left(t^{-1}\right)(t \rightarrow \infty)$ then $u$ is identically equal to zero throughout $R$.

This is an analogue to Protter's theorem [2], where parabolic operators of second order are considered.

2. To prove the theorem, we prepare two inequalities deduced from the following lemmas whose proofs are found in [1].

Lemin 1. Assume that the differential operator $A$ in (2) is uniformly elliptic in $R \cup S$. If $v$ is in $V$, if $f=f(t)$ is in $C^{1}([0, \infty))$ and if $g=g(t)$ continuous in $[0, \infty)$ has no zero, then there exist two positive constants $k_{1}$ and $k_{2}$ depending only on $A$ such that

$$
\begin{aligned}
& k_{1} \iint_{R} f^{2} \sum_{|\alpha| \leqq s}\left|D_{x}^{\alpha} v\right|^{2} d x d t \leqq \iint_{R} f^{2} g^{2}(L v)^{2} d x d t \\
& \quad+\iint_{R}\left(k_{2} f^{2}-2 f f^{\prime}+f^{2} g^{-2}\right) v^{2} d x d t+\lim _{t \rightarrow \infty} \int_{\mathscr{D}} f^{2} v^{2} d x .
\end{aligned}
$$

Lemma 2. Suppose that $v$ is in $V$ and that $f=f(t)$ is in $C^{\infty}([0, \infty))$ and $g=g(t)$ continuous in $[0, \infty)$ have no zero, then for a given operator $L$ in (1), there exists a constant $k_{3}$ depending only on $A$ such that 


$$
\begin{aligned}
& \iint_{R} f f^{\prime \prime} v^{2} d x d t \leqq \iint_{R} f^{2}(L v)^{2} d x d t \\
& \quad+k_{3} \iint_{R}\left(f^{2} g^{2}+f^{\prime 2} g^{-2}\right) \sum_{|\alpha| \leqq s}\left|D_{x}^{\alpha} v\right|^{2} d x d t \\
& \quad+\lim _{t \rightarrow \infty} \int_{\mathscr{D}} f f^{\prime} v^{2} d x .
\end{aligned}
$$

First, if $v \in V$, then by putting $f=e^{\lambda t}$ and $g=1$, Lemma 1 implies that there exists two positive constants $k_{1}$ and $k_{2}$ depending only on $A$ such that

$$
\begin{aligned}
& k_{1} \iint_{R} \mathrm{e}^{2 \lambda t} \sum_{|\alpha| \leqq s}\left|D_{x}^{\alpha} v\right|^{2} d x d t \\
& \quad \leqq \iint_{R} e^{2 \lambda t}(L v)^{2} d x d t+\iint_{R} e^{2 \lambda t}\left(k_{2}+1\right) v^{2} d x d t .
\end{aligned}
$$

Next, if $v \in V$, then by putting $f=e^{\lambda t}$ and $g=\sqrt{\lambda}$ it follows from Lemma 2 that there exists a constant $k_{3}$ depending only on $A$ such that

$$
\begin{aligned}
& \iint_{R} e^{2 \lambda t} \lambda^{2} v^{2} d x d t \\
& \quad \leqq \iint_{R} e^{2 \lambda t}(L v)^{2} d x d t+2 k_{3} \iint_{R} e^{2 \lambda t} \lambda \sum_{|\alpha| \leqq s}\left|D_{x}^{\alpha} v\right|^{2} d x d t .
\end{aligned}
$$

These are analogues to Protter's estimates, Lemma 3 and Lemma 4 in [2].

From (6) and (7), we get

$$
\begin{aligned}
\left(k_{1}-\frac{2\left(k_{2}+1\right) k_{3}}{\lambda}\right) \iint_{R} e^{2 \lambda t} \sum_{|\alpha| \leqq s}\left|D_{x}^{\alpha} v\right|^{2} d x d t \\
\leqq \\
\leqq\left(1+\frac{k_{2}+1}{\lambda^{2}}\right) \iint_{R} e^{2 \lambda t}(L v)^{2} d x d t, \quad v \in V .
\end{aligned}
$$

So, if $\lambda$ is sufficiently large, for instance, if $\lambda \geqq \lambda_{0}$, we have

$$
\begin{gathered}
\frac{k_{1}}{2} \iint_{R} e^{2 \lambda t} \sum_{|\alpha| \leqq s}\left|D_{x}^{\alpha} v\right|^{2} d x d t \\
\quad \leqq 2 \iint_{R} e^{2 \lambda t}(L v)^{2} d x d t
\end{gathered}
$$

for $v \in V$.

3. Now we give the proof of theorem. Let $\varphi=\varphi(t)$ be an infinitely many times differentiable function of $t$ such that 


$$
\varphi(t)=\left\{\begin{array}{cr}
0 \quad, & 0 \leqq t \leqq T_{1} \\
0<\varphi<1, & T_{1} \leqq t \leqq T_{2} \\
1 & , T_{2} \leqq t<\infty
\end{array}\right.
$$

for some $T_{1}$ and $T_{2}\left(T_{1}<T_{2}\right)$.

The function $v(x, t)=\varphi(\mathrm{t}) . u(x, t)$ is in the class $V$ and the inequality (8) is valid for $v$. We put

$$
R\left(T_{2}-T_{1}\right)=\mathscr{D} \times\left(I\left(T_{2}\right)-I\left(T_{1}\right)\right) \text { and } R\left(T_{2}\right)=\mathscr{D} \times\left(I-I\left(T_{2}\right)\right) .
$$

The inequality (8) implies that

$$
\begin{aligned}
& \frac{k_{1}}{2} \iint_{R\left(T_{2}\right)} e^{2 \lambda t} \sum_{|\alpha| \leqq s}\left|D_{x}^{\alpha} u\right|^{2} d x d t \\
& \quad \leqq 2 \iint_{R\left(T_{2}-T_{1}\right)} e^{2 \lambda t}(L v)^{2} d x d t+2 \iint_{R\left(T_{2}\right)} e^{2 \lambda t}(L u)^{2} d x d t .
\end{aligned}
$$

We substitute (5) into the last integral on the right and get

$$
\begin{aligned}
& \iint_{R\left(T_{2}\right)}\left[\frac{k_{1}}{2}-2 c(t)\right] e^{2 \lambda t} \sum_{|\alpha| \leqq s}\left|D_{x}^{\alpha} u\right|^{2} d x d t \\
& \quad \leqq 2 \iint_{R\left(T_{2}-T_{1}\right)} e^{2 \lambda t}(L v)^{2} d x d t .
\end{aligned}
$$

Since $\left.c(t)=0^{(} t^{-1}\right)(t \rightarrow \infty)$ by the assumption, we see that there exists a positive constant $\delta$ such that $k_{1} / 2-2 c(t)>\delta$ if $t \geqq T_{3}$ for some sufficiently large $T_{3}\left(>T_{2}\right)$. It holds that

$$
\iint_{R\left(T_{3}\right)} \sum_{|\alpha| \leqq s}\left|D_{x}^{\alpha} u\right|^{2} d x d t \leqq \frac{2}{\delta} e^{2 \lambda\left(T_{2}-T_{3}\right)} \iint_{R\left(T_{2}-T_{1}\right)}(L v)^{2} d x d t
$$

Since $\lambda\left(\geqq \lambda_{0}\right)$ is arbitrary, letting $\lambda \rightarrow \infty$, we see at once that $u \equiv 0$ in $R\left(T_{3}\right)$.

As $c(t)$ is bounded in $I$, we can apply the theorem in [1] for this function $u$ and we can conclude that $u$ vanishes throughout $R$.

\section{REFERENCES}

1. L. S. Chen and T. Kuroda, Unique continuation for parabolic equations of higher order. Nagoya Math. J. 26 (1966), 115-120.

2. M. H. Protter, Properties of solutions of parabolic equations and inequalities, Canada. J. Math. 13 (1961), 331-345.

Received June 14, 1965.

Department of Mathematics

Taiwan Provincial Cheng-Kung University, Tainan

and

Mathematical Institute

NAGOYA UNIVERSITY, NAGOYA 


\section{PACIFIC JOURNAL OF MATHEMATICS}

\section{EDITORS}

H. SAMELSON

Stanford University

Stanford, California

J. P. JANS

University of Washington

Seattle, Washington 98105

\section{J. DuGUNDJI}

University of Southern California

Los Angeles, California 90007

RICHARD ARENS

University of California

Los Angeles, California 90024

\section{ASSOCIATE EDITORS}

E. F. BECKENBACH
B. H. NEUMANN

F. WOLF

K. YoSIDA

\section{SUPPORTING INSTITUTIONS}

\author{
UNIVERSITY OF BRITISH COLUMBIA \\ CALIFORNIA INSTITUTE OF TECHNOLOGY \\ UNIVERSITY OF CALIFORNIA \\ MONTANA STATE UNIVERSITY \\ UNIVERSITY OF NEVADA \\ NEW MEXICO STATE UNIVERSITY \\ OREGON STATE UNIVERSITY \\ UNIVERSITY OF OREGON \\ OSAKA UNIVERSITY \\ UNIVERSITY OF SOUTHERN CALIFORNIA
}

\author{
STANFORD UNIVERSITY \\ UNIVERSITY OF TOKYO \\ UNIVERSITY OF UTAH \\ WASHINGTON STATE UNIVERSITY \\ UNIVERSITY OF WASHINGTON \\ AMERICAN MATHEMATICAL SOCIETY \\ CHEVRON RESEARCH CORPORATION \\ TRW SYSTEMS \\ NAVAL ORDNANCE TEST STATION
}

Mathematical papers intended for publication in the Pacific Journal of Mathematics should be typewritten (double spaced). The first paragraph or two must be capable of being used separately as a synopsis of the entire paper. It should not contain references to the bibliography. Manuscripts may be sent to any one of the four editors. All other communications to the editors should be addressed to the managing editor, Richard Arens at the University of California, Los Angeles, California 90024 .

50 reprints per author of each article are furnished free of charge; additional copies may be obtained at cost in multiples of 50 .

The Pacific Journal of Mathematics is published monthly. Effective with Volume 16 the price per volume (3 numbers) is $\$ 8.00$; single issues, $\$ 3.00$. Special price for current issues to individual faculty members of supporting institutions and to individual members of the American Mathematical Society: $\$ 4.00$ per volume; single issues $\$ 1.50$. Back numbers are available.

Subscriptions, orders for back numbers, and changes of address should be sent to Pacific Journal of Mathematics, 103 Highland Boulevard, Berkeley 8, California.

Printed at Kokusai Bunken Insatsusha (International Academic Printing Co., Ltd.), No. 6, 2-chome, Fujimi-cho, Chiyoda-ku, Tokyo, Japan.

\section{PUBLISHED BY PACIFIC JOURNAL OF MATHEMATICS, A NON-PROFIT CORPORATION}

The Supporting Institutions listed above contribute to the cost of publication of this Journal, but they are not owners or publishers and have no responsibility for its content or policies. 


\section{Pacific Journal of Mathematics

Vol. 19, No. $3 \quad$ July, 1966

S. J. Bernau, The spectral theorem for unbounded normal operators .......

Lu-san Chen, Asymptotic behavior of solutions of parabolic equations of

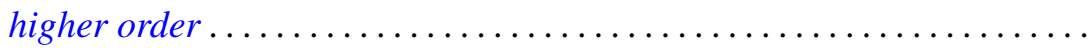

Lawrence William Conlon, An application of the Bott suspension map to the

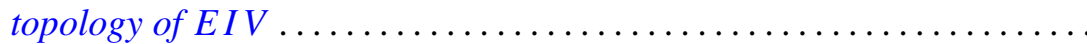

Neal Eugene Foland and John M. Marr, Sets with zero-dimensional kernels .........................................

Stanley Phillip Franklin and R. H. Sorgenfrey, Closed and image-closed

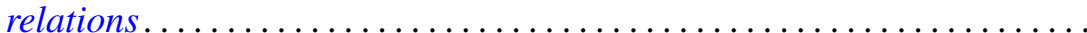

William Jesse Gray, A note on topological transformation groups with a

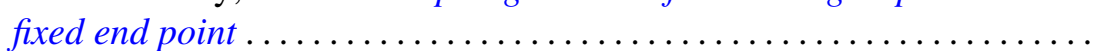

Myron Goldstein, $K$ - and L-kernels on an arbitrary Riemann surface ...... 449

George Joseph Kertz and Francis Regan, The exponential analogue of a generalized Weierstrass series .............................

Walter Leighton, On Liapunov functions with a single critical point ........ 467

Bernard Werner Levinger and Richard Steven Varga, On a problem of $O$.

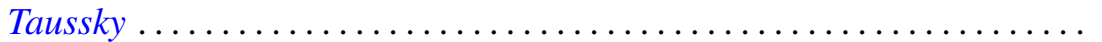

Lowell Duane Loveland, Tame subsets of spheres in $E^{3} \ldots \ldots \ldots \ldots \ldots . .489$

Erik Andrew Schreiner, Modular pairs in orthomodular lattices ......... 519

K. N. Srivastava, On dual series relations involving Laguerre polynomials ...............................

Arthur Steger, Diagonability of idempotent matrices.....

Walter Strauss, On continuity of functions with values in various Banach spaces...

Robert Vermes, On the zeros of a linear combination of polynomials ...

Elliot Carl Weinberg, On the scarcity of lattice-ordered matrix rings ....

Harold Widom, Toeplitz operators on $H_{p} \ldots \ldots \ldots \ldots \ldots$

Neal Zierler, On the lattice of closed subspaces of Hilbert space...

Irving Leonard Glicksberg, Correction to: "Maximal algebras and a theorem of Rado"

John Spurgeon Bradley, Correction to: "Adjoint quasi-differential operators of Euler type"

William Branham Jones, Erratum: "Duality and types of completeness in locally covex spaces".

Stanley P. Gudder, Erratum: "Uniqueness and existence properties of bounded observables" 